\title{
Impact of Interest Rate on Stock Market; Evidence from Pakistani Market
}

\author{
Hamdan Ali \\ (MBA (C) - Finance) Foundation University Islamabad (Pakistan)
}

\begin{abstract}
This research paper was an endeavor to make a model, to find out the connection involving stock market and interest rate (Pakistani market) and to run certain tests related to statistical analysis. These tests run with the help of month end closing stock prices of Karachi Stock Exchange and interest rates of previous ten years i.e. Jan 2004 to Dec 2013. Correlation, Regression analysis and descriptive analysis were run to find out the blow of interest rate on stock market of Pakistan. Performance of Pakistani Stock market is highly dependent on political situation. The most important factor of any country's economy is its Stock market. But there are certain factors which have negative and positive impact on stock markets. Here I am considering one factor that has impact these are inversely related with each other i.e. one increases other decreases and vice versa.
\end{abstract}

Keywords: Stock Market, Interest Rate, Karachi Stock Exchange and Stock Market Index.

\section{Introduction}

Stock exchanges are entity which provides dealing amenities for stash negotiator and dealer, to buy and sell stocks and other securities. Pakistan Stock Market has three main stock markets KSE, LSE and ISE. Stock interactions have numerous responsibilities in the financial system such as drumming up reserves for speculation, assists corporation development, revenue sharing, chances for diminutive financiers.

Among these stock exchanges Karachi Stock Exchange is the oldest one which was time-honored on Sep 18, 1947 after two months of independence of Pakistan. It is growing day by day. Ups and downs come across KSE in regular intervals due to Political instability, security threats and other macro-economical issues but nowadays it is showing progress positively. There are two types of indexes; KSE-30 Index and KSE-100 Index.

KSE-30 index, 10K spots were launched as the support worth. It is somehow different from other types of indices. The main difference is that it is supported by free float of splits instead of paid up assets.

KSE-100 index is rapidly growing index in Pakistan and it is known as emerging market of Asia. 2013 was the best year in the history of Stock market of Pakistan. On December $31^{\text {st }}$ record of 25,261 points occurred which is a great achievement. Here are five top companies in KSE-100 index with market capitalization and weight age.

\begin{tabular}{|l|l|l|l|}
\hline No. & Corporation Name & Weight age (\%) & $\begin{array}{l}\text { Market Capitalization (PKR) } \\
\text { in Million }\end{array}$ \\
\hline 1 & OGDCL & 14.14 & 550,949 \\
\hline 2 & MCB Bank & 7.17 & 279,583 \\
\hline 3 & NBP & 5.43 & 211,727 \\
\hline 4 & Pakistan Petroleum & 5.06 & 197,201 \\
\hline 5 & SCB & 4.41 & 171,705 \\
\hline
\end{tabular}

This study determines the impact of interest rate on stock market of Pakistan. The selected market for detailed analysis is stock market of Pakistan. This paper will analyze the effects of interest rate on stock market of Pakistan. For this purpose, quantitative research method is used based on the data from 2004 to 2013 on monthly basis. As sustain software, Microsoft Excel is used for a range of calculations. Hypothesis is tested using Regression Analysis. The research reveals connection between interest rate and stock market. The most important intention of this research is to study the relationship between Interest rate and stock market of Pakistan.

Interest is a charge paid by a borrower of material goods to the owner as a type of return for the utilization of the assets. It is basically the price paid for the use of owner's money or any material goods. It may be the money earned by deposited finances for a certain period of time. Interest Rate is the price at which interest is paid by a debtor for the utilization of money or any property that they borrow from a creditor. It is set for a period of time mostly annually. E.g. if someone borrows one hundred rupees with the interest rate of nine percent per annum then he has to pay one hundred nine rupees after one year. 
It is more uncertain for a country's stock market to have a high interest rate. It has also been found that on the outcome of Interest rate; when it is raised, the general effect is a decrease of the amount of money in spread, which helps to keep inflation near to the ground. It also makes borrowing money more difficult, which affects the investment criteria of that country. Everyone will try to lend his assets on high interest rate. This increases expenses for companies, decreases earnings somewhat for those with debt to pay. And the result will be the tuff to take decision to invest in the stock market.

Research's objectives include: To know the relationship between interest rate and stock market, to know the effect of interest rate on stock market and its performance and to enhance knowledge to take right decisions if needed. The scope of the research is applicable to the stock market of Pakistan, as the primary data collection due to the limited time and resources that are conducted in only one country. Moreover research has given a good enough to guide the new researcher in this field and help the financial managers in planning and organizing their investments. The shared financing policies in Pakistan are not very reverberation similarly institutional growth is fewer viable. All these factors have led to a highly interest rate stock market and provide the coherent for studying the interest rate effect in relation to the stock prices on the KSE. The time period is spread over ten years (Jan 2004 to Dec 2013), so that the good time perspective is provided.

\section{Literature Review}

According to researchers of almost every era it is not wrong to say that stock market of any country plays a vital role for economic growth. But there are many factors which do have an impact on stock market. These factors may lessen the performance or may increase. Government of each country should enhance the factors which enhance the performance of stock market and discourages those factors which have diverse impact on stock market. As it is the study of interest rate and stock market I found from almost each and every paper and article that interest rate has a negative impact on stock market. More the interest rate lessens the efficiency of stock market. Some of reviews about these variables and relationship between these variables are discussed in this paper which will help us to understand this topic more deeply.

Richid (1981) claims that predicted inflation is unenthusiastically interrelated with expected authentic activity, which is at the same time positively correlated to stock market's returns. Thus, it can be said that stock market returns is negatively correlated with expected inflation.

Campbell (1987) contends that variables which have been used to guess surplus returns should also foretell excess stock returns. Ling (1990) premeditated expected inflation and stock market. He also focused the relationship between each other.

Davidson (1996) hit upon the relationship between both variables. He used regression analysis to find this relationship. He also come across that there is an important impact of interest rate on stock market. His results were focusing on the long-term interest rates which play a fundament role of deviation in price dividend ratios.

Kunt (1996) have found that countries with lesser interest rate have strong stock market as compared to countries which have higher interest rate. They also mentioned that developed countries are usually having low interest rates due which their stock market's performance is extra-ordinary.

Kelen (2000); they worked on developing markets i.e. Zimbabwe, South Africa and Botswana; where higher interest rates think to a great loss for stock market and its prices. He concluded that there is a negative relationship between both variables. Higher interest rate will deteriorate stock market.

Harasty and Roulet (2000) performed work on more than 17 countries i.e. developed ones. He finished with a result that stock prices are incorporated with income from dividends and interest rate of each country he studied except Italy.

Spyrou (2001) also worked to find out the relationship between inflation and stock returns of Greece. He continued Kaul's research and came to know that these are negatively related but this conclusion was up to 1995 later on this relationship became irrelevant.

Arango (2002) studied Bogota stock market and he also found negative relation between both variables i.e. stock market and interest rate but his findings didn't help out the central souk of Colombia.

Hsing (2004) used VAR model to find out the purpose and impact of different variables on each others. Variable were interest rate, exchange rate and stock market. But he concluded the same result i.e. negative relationship between stock market and interest rate.

Zordan (2005) worked with macro factors i.e. World War II and he also found opposite relation between both variables. He also focused on cycle's research.

For example: ten to fifteen years etc.

SalahUddin (2009) studied two important factors which are involved in a country's growth or reduction i.e. stock exchange and interest rate. Interest rate effects not only on stock market but monetary policy also. SalahUddin investigated the impact of interest rate on stock market with the help of monthly data of almost fifteen years and sample was also of fifteen countries few of them were developed and rests were developing. 
After his tests he concluded that there is a significant negative relationship between stock market and interest rate. Zahid (2010) studied variables related to macro economics and stock market index. And he found that impact of interest rate and inflation has negative impact on stock market. He also claimed that positive but not a strong relation on stock market of Pakistan

\section{Methodology}

The data about relevant variables has been obtained from "Global economy, International Financial Statistics (IFS), KSE, State Bank of Pakistan, International Monterey Funds (IMF) and other resources." I will investigate stock market of Pakistan and will gather the statistics ranging over a period of ten years preliminary from 2004 to 2013. Applicable variables are: Interest Rate, Stock Market Index and Stock Market

Data collected from various resources for our research. Information is obtained by the help of articles, journals, books, official websites, KSE, LSE, ISE, International Monetary Fund, Global Economy, colleagues, professors etc. Data for literature review was gathered from Articles from Pakistan Development Review, KSE, Finance books, Daily trading documents, Annual reports, State Bank of general Index of Share prices, , research articles from various journals via online databases. I will also use different records and historical data. Moreover some information was collected from different websites; the detailed references of these websites are given at the end. I will examine the data of Stock market of ten years; 2004-2013. Quantitative research method is used for this Research Paper.

The purpose of this research is to gather awareness through theories and information that already been found out and then at last generate 'hypothesis' from these studies and lay it in practical study. The moneymaking speculation is mainly based on the studies from books, published articles and internet sites, trade with economic subjects to give a theoretical base for the examination.

The research uses tools such as 'Descriptive Statistics' and 'Regression Analysis' and "Co-relation".

Theoretical Framework: In this stride I will narrate Variables; dependent and independent variables which will assist me as a foundation for the entire work. As I am assuming that variables are Stock Market; i.e. dependent and independent variables are interest rate, inflation rate and gross domestic product growth rate.

\section{Theoretical Framework}

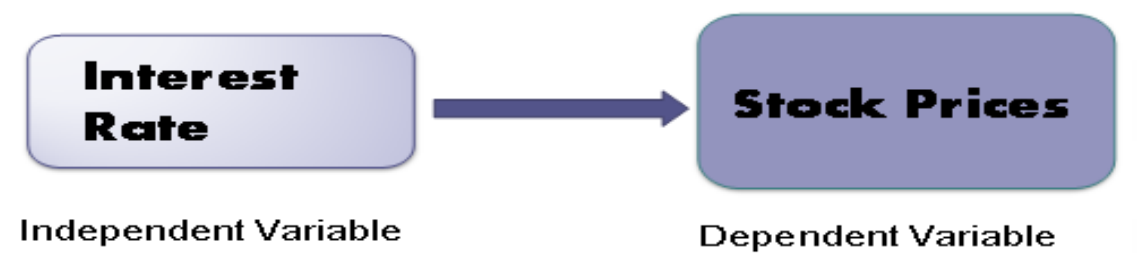

Theoretical Work

The theoretical framework is the vivid demonstration of this affiliation consequent in the light of preceding prose accessible; the research has well thought-out Stock market as a dependent variable and interest rate, inflation rate and gross domestic product growth rate as the independent variables.

Purpose of Research is to find out the relationship between stock market and interest rate a hypothesis is used. Here I also mentioned two expected hypotheses that will show relation between these variables. It was unproblematic for me to make a research hypothesis. The relationships among the variables are recognized on the origin of preceding literature presented. These relationships can be confirmed by means of definite arithmetic tests/techniques. Two hypotheses are to be researched in order to find the relationship between two variables. I will try to prove them with the help fonts and more by statistical apparatus.

Hypothesis; following are the two hypotheses which can be made by studying the literature review and introduction.

Null Hypotheses (H0): There is no significant relationship between interest rate and the stock market.

Hypothesis (H1): There is significant relationship between interest rate and the stock market.

This research has been carried out with special orientation of stock market; stock market index used that was readily available on KSE. Data is used on yearly basis as it was for ten years for more deep study. Sample size is the stock market index and interest rates of 120 months. The study utilizes tools such as "Descriptive Statistics, 
Regression Analysis and Correlation". The results of the study are expressed in "sets of tables". To test the hypothesis, the "Regression Analysis Model" will be used.

\section{Findings And Results}

For findings and results I will run certain tests one by one mentioned below:

Descriptive Statistics, Correlation and Regression Analysis

Descriptive Statistics; as there are two variables so we will find descriptive statistics for everyone. Descriptive statistics includes:

Mean

Standard Error

Median

Mode

Standard Deviation

Sample Variance

Kurtosis

Skewness

Range

Minimum

Maximum

Sum

\begin{tabular}{|l|l|l|l|}
\hline Stock Market & & Interest Rate & \\
\hline Mean & 11377.29 & Mean & 12.82 \\
\hline Standard Error & 404.93 & Standard Error & 0.17 \\
\hline Median & 10844.67 & Median & 12.96 \\
\hline Mode & 7104.65 & Mode & 10.08 \\
\hline Standard Deviation & 4435.77 & Standard Deviation & 1.90 \\
\hline Sample Variance & 19676091.02 & Sample Variance & 3.62 \\
\hline Kurtosis & 1.13 & Kurtosis & -1.00 \\
\hline Skewness & 1.00 & Skewness & 0.16 \\
\hline Range & 20420.77 & Range & 6.72 \\
\hline Minimum & 4840.37 & Minimum & 10.08 \\
\hline Maximum & 25261.14 & Maximum & 16.80 \\
\hline Sum & 1365274.78 & Sum & 1538.76 \\
\hline Count & 120.00 & Count & 120.00 \\
\hline
\end{tabular}

Table 1: Descriptive analysis

Correlation; There are two types of correlation.

Direct correlation or constructive correlation and Indirect correlation or unconstructive correlation

I used Correlation to know the strength and direction between variables.

\begin{tabular}{|l|l|l|}
\hline & Stock Market & Interest Rate \\
\hline Stock Market & 1 & \\
\hline Interest Rate & $(0.25)$ & 1 \\
\hline
\end{tabular}

Table 2: Correlation between Variables

Below mentioned criteria indicates the intensity of relationship between variables.

\begin{tabular}{|l|l|}
\hline Correlation $<0.20$ & Weak relation \\
\hline Correlation $\geq 0.2$ but $<0.5$ & Moderate relation \\
\hline Correlation $\geq 0.5$ up to 1 & Strong relation \\
\hline
\end{tabular}

Table 3: Correlation Measures

From the above mentioned test we can say that there is a negative moderate relation between stock market and interest rate. Moderate because its value is greater than 0.20 which is an indicator of moderate relation.

Regression Analysis; I find regression between dependent and independent variables. Regression includes various factors like Multiple R, R square, Adjusted R square, Standard Error, and Number of observations, PValue, T- Stat, Coefficient and significance F. 
R Square is the descriptive replica that let us know that how much proportion of variation is explained by selfsufficient variables. Coefficient shows the change in the dependent variable with the change of 1 unit in the independent variables.

If significance $\mathrm{F}$ is less than or equal to 0.05 than it is significant and if it is greater than 0.05 then it is insignificant.

Regression equation; A straightforward linear regression is a waning in which there is only one forecaster variable. Simple linear regression is utilized in circumstances to estimate the linear association linking two variables. A regression stripe is the line described by the equation and the regression equation is the formula for the line.

$\mathrm{Y}(\mathrm{SMI})=\alpha+\beta 1$ (interest rate) $\mathrm{x}$

$\mathrm{Y}$ is a Dependent Variable

$\mathrm{X}$ is an Independent Variable

" $a$ " is the intercept b is the slope,

$\mathrm{x}$ is the residual of regression.

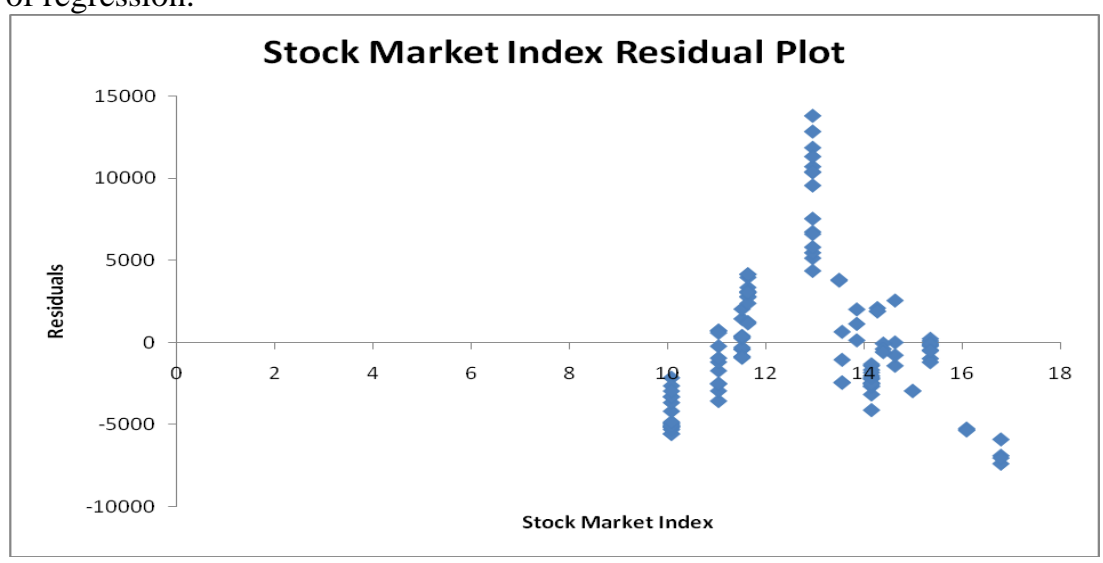

Figure 1: Stock Market Index Residual Plot

SUMMARY

OUTPUT

\begin{tabular}{lc}
\hline \multicolumn{2}{c}{ Regression Statistics } \\
\hline Multiple R & 0.15 \\
R Square & 0.02 \\
Adjusted R & \\
Square & 0.01 \\
Standard & \\
Error & 0.69 \\
Observations & 120 \\
\hline
\end{tabular}

ANOVA

\begin{tabular}{lrrrrr}
\hline & & & & \multicolumn{2}{c}{ Significance } \\
& $d f$ & \multicolumn{1}{c}{ SS } & $M S$ & $F$ & $F$ \\
\hline Regression & 1 & 34.05 & 54.1 & 2.74 & 0.10 \\
Residual & 118 & 45.78 & 53.2 & & \\
Total & 119 & 41.32 & & & \\
\hline
\end{tabular}

\begin{tabular}{lrrrrrrrr}
\hline & Coefficients & \multicolumn{1}{c}{$\begin{array}{c}\text { Standard } \\
\text { Error }\end{array}$} & \multicolumn{1}{c}{ t Stat } & $\begin{array}{c}\text { Palue } \\
\text { valuer }\end{array}$ & Low\% & $\begin{array}{c}\text { Upper } \\
95 \%\end{array}$ & $\begin{array}{c}\text { Lower } \\
95.0 \%\end{array}$ & $\begin{array}{l}\text { Upper } \\
\text { 95.0\% }\end{array}$ \\
\hline Intercept & 687.98 & 9.83 & 2.50 & 0.01 & 18.56 & 19.40 & 18.56 & 19.40 \\
X Variable 1 & 351.19 & 22.14 & 1.66 & 0.10 & -68.91 & 71.29 & -68.91 & 71.29 \\
\hline
\end{tabular}

Table 4: Regression Analysis

First come the R square; as it is regression of stock market index and interest rate of ten years on monthly basis. After test we found that the value of $\mathrm{R}$ Square is 0.02 which means that two percent variation in stock market index is explained by the interest rate. The values of Multiple R, adjusted R square and standard error are 0.15 , 0.01 and 4403 respectively. The value of Significance $F$ is less than 0.05 so we can say that relation is significant, because anything less than 0.05 is called a significant and vice versa. Coefficient show the change occurs in dependent variable with the 1 unit change in independent variable. E.g. one unit change in interest rate represents 0.67 i.e. 67 percent change occurs in stock market index. P-value is less than 0.05 that shows a 
significant relationship between interest rate and stock market index. The higher interest rate can harm the economy of any country.

\section{Conclusion}

From the previous studies and my findings now it is easy to say that interest rate has a negative impact on stock market, higher the interest rate lower the efficiency of stock market, it is because if investors are getting higher without taking any risk then why should they invest in stock market, so for a better economy the ruling state should lower its interest rate so that economy of that country gets developed. It is not the only factor that has negative impact on stock market there can be many other factors for example inflation rate etc which are having negative impact on stock market.

\section{References}

[1]. Groenewold, N., Tang, S. H. K. and Y. Wu (2003), "The Efficiency of the Chinese Stock Market and the Role of the Banks", Journal of Asian Economies, 14, 593-609.

[2]. Campbell, J.Y. (1987). Stock Returns and the Term Structure. Journal of Financial Economics, 18, 373-399.

[3]. Jammine, A.P. and Hawkins, D.M.(1974). The Behavior of Some Share Indices: A Statistical Analysis. The South African Journal of Economics, 42(1), 43-55.

[4]. Poterba, J. M. and Summers, L. H. (1988). Mean Reversion in Stock Returns: Evidence and Implications. Journal of Financial Economics, 22, 27-59.

[5]. Valeriano F. Garcia(1999), Macroeconomic determinants of stock market development, Journal of Applied Economics, mayo, vol.2.

[6]. Mehwish Zafar (2013) Determinants of stock market performance in Pakistan interdisciplinary journal of contemporary research in business, 1017-1021

[7]. Hung-Chun Liu, Abdul Haque and Fakhar-Un-Nisa (2011), Testing The Weak Form Efficiency of Pakistani Stock Market (20002010), International Journal of Economics and Financial Issues 153-162

[8]. Pablo Martínez-Moya (2013) Relationship between interest rate changes and stock returns in Spain: A wavelet based approach

[9]. ABID HAMEED and HAMMAD ASHRAF*(2006) Stock Market Volatility and Weak-form Efficiency: Evidence from an Emerging Market The Pakistan Development Review 45 : 4 Part II (Winter 2006) pp. 1029-1040

[10]. Aydemir (March 2007), Financial Leverage And The Leverage Effect - A Market And Firm Analysis, Tepper School Of Business. Paper 142.

[11]. Affect of Leverage on Risk and Stock Returns: Evidence from Pakistani Companies by Afkar Majeed Bhatt, International Research Journal of Finance and Economics Page No. (32-48) 